\title{
The Working Conditions In The Mining Sector: The Case Of Mchenga And Kaziwiziwi Coal Mines In Malawi
}

\author{
Kalani Mbeye Malema \\ Ministry of Labour - Malawi Government, Malawi \\ *Corresponding Author: Kalani Mbeye Malema: kalani.malema@gmail.com
}

\section{OPEN ACCESS}

Citation: Malema K. M. (2017) The Working Conditions In The Mining Sector: The Case Of Mchenga And Kaziwiziwi Coal Mines In Malawi. Open Science Journal 2(1).

Received: $26^{\text {th }}$ January 2017

Accepted: 20 ${ }^{\text {th }}$ March 2017

Published: $31^{\text {st }}$ March 2017

Copyright:@ 2016 This is an open access article under the terms of the Creative Commons

Attribution License, which permits unrestricted use, distribution, and reproduction in any medium, provided the original author and source are credited.

Funding: The author(s) received no specific funding for this work.

\section{Competing Interests: The} author have declared that no competing interests exists.

\section{Abstract}

The purpose of this paper is to examine the working conditions in the mining sector in relation to Mchenga and Kaziwiziwi coal mines in Rumphi district in Malawi. The paper reports that the working conditions in the mining sector are generally poor and that the workers' organizations and their activities in the mining sector are effective tools for the improved working conditions. The paper however, argues that, to a greater extent, it is over expectations compounded by lack of knowledge on part of (amongst the) the employees and/or the community members around the mining workplaces regarding aspects of legal and non legal liabilities of the workplace employers towards the implementation of labour practices and of corporate social responsibility interventions that complicates the sufferings of most mining sector employees in Malawi. It is thus important to encourage the establishment of workers' organizations at a workplace and for stakeholders such as Civil Society Organizations to be conclusive in their complementary roles to government when it comes to the implementation of advocacy activities to the communities (employees) around the mining workplaces especially in the event that such activities' implications have potential effects to cause some forms of conflicts between the mining workplace employers and their employees including the surrounding community members thereby likely to complicate workers' sufferings as a result of some unresolved consequences. 
Keywords: Working conditions, Mining sector, Labour practices, Labour Rights, Corporate Social Responsibility, Workers' organizations, Collective bargaining.

\section{Introduction}

Towards the end of the year 2012, Tilitonse, a grant-making facility for Malawian based Civil Society Organizations (CSOs) in conjunction with the United Kingdom department for International Development (DFID) together with the Royal Norwegian Embassy and Irish Aid launched a thematic call for project proposals to undertake activities in the mining sector in Malawi. As a result, in April 2013, the Malawi's Catholic Commission for Justice and Peace (CCJP) of the Karonga Catholic Diocese and the Church and Society Programme (CSP) of the CCAP Livingstonia Synod secured funds to implement projects in the mining communities.

Thus from April 2013 to 2014, CSP implemented a project known as "Advocacy Campaign for an Inclusive and Accountable Extractive Industry" valued at approximately US\$27,500. This project targeted Mchenga Coal Mines (MCM) Company. According to the programme Deputy director, Jacob Nkhambule, the inspiration to run such a project was based on their 2007 assessment which had revealed a lack of tangible corporate social responsibility interventions coupled with poor compensation and low benefits for the communities (including employees) from the mining sector activities. Whereas CCJP implemented a US $\$ 35,000$ valued project known as "Mining Industry Advocacy Capacity Building" project that targeted Kaziwiziwi coal mining. According to CCJP father Denis Chitete, their project aims were to ensure that poor people at Kaziwiziwi know their rights, demand them and defend them in cases of violations in addition to ensuring the need to protect the natural resources so that they benefit Malawians most.

Following the implementation of the two mining advocacy projects, employees of both Mchenga and Kaziwiziwi coal mines together with their respective mine workplaces' community members were capacitated in terms of knowledge of their rights and started demanding for such from the mining workplace employers. In the course of doing so, several workplace conflicts erupted at the two mining workplaces some of which became too complex. These conflicts ranged from labour disputes through non labour disputes to land disputes. All these were to be addressed by the State through its mandated government department officials - the duty bearers, the work that became ongoing from mid 2013 towards the end of 2014 and beyond. The author of this paper, who was among the government officials handling various conflicts between the mine employees and their employers was thus prompted to examine the working conditions in the mining sector with a focus to Mchenga and Kaziwiziwi coal mines in Rumphi district by trying to answer the questions such as What are the actual working conditions mainly in terms of labour under which the mining sector employees operate and How best can the CSOs be coordinating 
with government duty bearers in their advocacy activities being implemented within the mining sector communities?

In the course of investigating the working conditions, the author undertook various discussions with various stakeholders including the CSOs and the mine workplace employers and employees' representatives, examined reports and available documentary reports and labour disputes settlement reports maintained at Rumphi district labour office. Before presenting a discussion of the results with respect to the mine working conditions, this paper first presents literature review that includes a brief outline of the minerals mining in general and coal mining in particular and also an examination of the regulatory frameworks of the mining industry in Malawi including the country labour legislative frameworks.

\section{Literature Review}

\section{Minerals Mining in Malawi}

The Minerals mining in Malawi involves several mining activities that range from the artisanal small scale mining (ASSM) activities through the medium to large scale mining (MLSM) activities [1]. These Malawi's mining activities include the production of cement, coal, crushed stones, dolomite, kaolin, lime, lime stones and sulfuric acid and bentonite and uranium, gemstones (as a methyst, garnet, ruby, sapphire and tournaline), and ornamental stones (as agate and rose quartz) for domestic consumption and exporting respectively [2]. Whereas, the Malawi Mines and Mineral policy of 2007 [3] shows Malawi's variety of solid mineral resources such as bauxite, uranium, niobium, tentalum, monazite, strontianite, corundum, graphite, limestone, titanium, heavy sands, vermiculite, coal, phosphate, pyrite, glass sands, dimension stones, and gemstones. However, those produced or to be produced at a relatively medium to large scale and mostly owned or controlled by the private sector companies include uranium (largest mining activity) at Kayerekera in Karonga, coal (second largest mining activity) within the Livingstonia hills at Mchenga, Kaziwiziwi and other locations in Rumphi and Karonga (Eland / Nkhachila coal mining at Mwabulambo) districts, gemstones (precious and semi-precious stones such as ruby and sulphur which are largely produced in Mzimba followed by Chikhwawa and Ntcheu districts, Calcitic and hydrated lime in Balaka (also with Kangankunde rare-earth elements) and at Lirangwe in Blantyre, rock aggregates (quarry stones) in a total of 12 registered quarry production sites in the country, Niobium (under exploration stage) at Kanyika in Mzimba and cement limestone (also under exploration stage) in Mangochi and around Bwanje area in Ntcheu-Dedza districts.

Mining has become an important issue in Malawi because of its potential to significantly contribute to Malawi's Gross Domestic Product (GDP). For instance, it is currently estimated that the contribution of the mining sector to the country's GDP has grown from as low as $1 \%$ by the year 2001 to about $3 \%$ by 2004 and to $10.8 \%$ by 2010 as a result of commissioning of the Kayerekera uranium mining in $2009[1,4,5,6]$. Furthermore, it is projected that a wellmanaged mining sector could contribute between 20 and $30 \%$ of Malawi's GDP 
in the next 5 years. Since Malawi has identified or prioritized mining as one of the potential key sectors for the country's economic growth [7] and that the country has shown its commitment to continue considering the issuing of various mining related licenses to potential investors, there is need to explore on how best the mining sector can be managed in order to realize the sector's projected contributions of $30 \%$ towards the country's GDP. Among other things therefore to be explored, is the working conditions of the country's mining sector employees since Malawi mining operations are still labour intensive and that it is only the health and well motivated workforce (labourers) that can lead into high workplace productivities out of free industrial disputes that are detrimental to workplace production activities and hence positive contribution towards the anticipated well-management of the mining sector operations in Malawi.

In relation to the generated employment opportunities which are one variable factor in any working conditions study, the Malawi Government 2012 Annual Economic report [8] indicates that a total of 21,022 workers were employed in the mining sector by 2011 representing an increase of $82 \%$ from 11,565 in 2009. Of the total 2011 sector employees, 907 were in coal, 859 in uranium mining activities, 12,030 in the quarry aggregate production, 1,260 in gemstones minerals specimens, 195 in minerals exploration activities and the rest in other mineral production activities.

\section{Coal Mining in Malawi}

Malawi has over 22 million tons of proven coal reserves in a number of coal fields across the country [8]. The largest coal field is the Livingstonia coal field with probable reserves of over 2-5 million tones and proven reserves of 4 million tons of coal with ash content of $17 \%$, a sulphur of $0.5 \%$ and a calorific value of $6,800 \mathrm{kcal} / \mathrm{kg}$. Livingstonia coal field is a $90 \mathrm{~km}^{2}$ stretch in Rumphi district in the Northern Region of Malawi [8].

CPL- Mchenga, Kaziwiziwi and Eland/Nkhachila coal mines are the three major coal mining companies producing coal in Malawi. CPL - Mchenga and Kaziwiziwi coal mines are within the Livingstonia coal field whereas Eland/Nkhachila is a coal mining company at Mwabulambo in Karonga. All these coal companies produce coal for industrial use in cement, tobacco, sugar, tea, brewery, textile, and food processing and ethanol companies. Other coal mining companies of which some are operational but on small scale and some are abandoned or suspended include Mean Jalawe, Phoka, Chiweta, David duwi at Livingstonia and Chombe/Thekero coal mines, all in Rumphi district.

The total produced coal by all coal mining companies, which make an average of 10,000 metric tons of coal per month, still falls short of the market demand in Malawi [8]. The coal mining companies primarily supply their coal products to the country's local market. However, for the international market, 20 $\%$ of the produced coal is exported to Tanzania cement factories by Eland coal mining company. This exported coal by Eland company is washed coal grit (the processed coal and free from impurities) which fetches high market value than the non washed coal [8]. 


\section{The Mining Regulatory Frameworks}

Three mining regulatory frameworks that were necessary to be outlined in this paper are the institutional, the policy and the legislative frameworks. However, only the policy and legislative frameworks have been outlined, to show legal basis for the mining activities in Malawi as well as to understand the necessity of discussing the working conditions in the mining sector.

\section{The 2013 Mines and Minerals Policy of Malawi}

Malawi has Mines and Minerals Policy whose main objectives are: to contribute to socio-economic development of the country including poverty reduction and sustainable development; to optimize mining activities within Malawi so as to enhance "value added" elements of the sector and promote linkages with other sectors of the economy; to promote women in the mining and to expand employment opportunities in Malawi among others. With regard to environmental management, the policy contains guidelines that would enable government to ensure environmentally sustainable mining practices which will be consistent with international standards so that challenges where some mining companies do not comply with international standards in occupational health and safety and those where mining activities cause environmental degradation be addressed. In addition, the policy prescribes guidelines that would ensure that mining related social issues are adequately addressed. Some identified social issues connected with the mining activities in Malawi include: inadequate empowerment of local people; lack of articulated social responsibilities for mining companies; disruption of families and social structures due to HIV/AIDS and other diseases; child labour; as well as compensation and resettlement of land owners and communities affected by the mining just to mention but a few. The mining policy is complemented by the National Environmental Management policy of 1996. To encourage the provision of health and social facilities through corporate social responsibility, the policy directs mining companies to construct clinics and other social facilities as well as to allow access to the clinic and other constructed social facilities by local communities.

\section{Corporate Social Responsibility}

Corporate social responsibility refers to all the interventions to be undertaken by the company in order to help address the company's operational impact on society and the environment. It is necessary for the company to undertake such interventions, although not a legal requirement, because failure to do so may result into the company suffering direct losses as a result of their actions through the cost of rectifying environmental damage, fines and taxes as well as through their adverse publicity costs if their business is believed to cause damage to the environment.

Although the corporate social responsibility interventions are necessary, they are just soft law interventions to promote corporate responsibility. Soft law interventions are non regulatory interventions [9]. This means that they are not legal requirements. Examples of soft law policies include corporate governance codes, codes of conduct, the promotion and implementation of the universal international principles and guidelines for corporate responsibility such as the UN Global Compact and the Organisation for Economic Co-operation and 
Development (OECD) guidelines for multinational enterprises. These soft law policies offer an attractive complement to legislation. OECD [10] is a unique forum where the Governments of 30 democracies work together to address economic, social and environmental challenges of globalization. The OECD member countries are: Australia, Austria, Belgium, Canada, the Czech Republic, Denmark, Finland, France, Germany, Greece, Hungary, Iceland, Ireland, Italy, Japan, Korea, Luxemburg, Mexico, the Netherlands, New Zealand, Norway, Poland, Portugal, the Slovak Republic, Spain, Sweden, Switzerland, Turkey, the United Kingdom and the United States. The Commission of the European Community also takes part in the work of the OECD.

Legal frameworks for corporate social responsibility vary widely depending on a country's social economic and cultural framework. It should, however, be noted that although corporate social responsibility is generally considered a voluntary tool, a number of governments have implemented mandatory measures in recent years that oblige companies to report on their corporate social responsibility associated business activities [9].

In Malawi, the Malawi Code II for Corporate Governance of 2010 [11] is a soft law tool that guides the implementation of corporate social responsibility interventions. Clause 16.3 of the Malawi corporate governance code (MCGC) on ethics stipulates that organizations should "allow African 'Umunthu' values to thrive within the ethical framework of the organization" and clause 17.1, on good citizenship, stipulates that "an organization as well as being an economic entity is also a citizen of Malawi and as such has a moral and social standing within Malawian society, with all the responsibilities attached to that status. As such, when making decisions, an organization should consider the impact of its decisions on its stakeholders (both internal and external), the environment and society as a whole".

Whereas, the implied legal framework for corporate social responsibility is provided for, in the Malawi Environmental Management Act of 1996 and in the Mines and Minerals Act (MMA) of 1981 (Cap. 61:01) [12]. For instance, section 94 (1) of the MMA provides that: "in deciding whether or not to grant a mineral right, the Minister shall take into account the need to conserve the natural resources in or on the land over which the mineral right is sought, or in or on neighbouring land". Furthermore, section 95 (1) of the same mines and minerals Act provides that "there may be included in a mineral right conditions with respect to (a) the prevention, limitation or treatment of pollution; (b) the minimization of the effects of mining on adjoining or neighbouring areas and their inhabitants". Mineral Right is defined in the Mines and Minerals Act of 1981 (Cap. 60:01) [12] to mean a reconnaissance license or an exclusive prospecting license or a mining license. The use of the word "may" in section 95 (1) of the Act entails that legally, it is not a must for the mineral right conditions to include provisions requiring companies to undertake corporate social responsibility interventions in Malawi. Thus a company in Malawi is still at liberty to or not to undertake some corporate social responsibilities within the workplace environment. This law on its own, and in the event where workplace employees and the community around do not know about such optional provisions and its meaning or implication which is often the case in Malawi, is one major source of conflict between the workplace owners (the employers) and the employees together with the workplace surrounding community members as a whole. 


\section{Mining Legislative Framework in Malawi}

Four legislative Acts regulate the minerals sector in Malawi. These are the Explosives Act of 1968; the Mines and Minerals Act of 1981; the Petroleum (Exploration and Production) Act of 1983; and the Atomic Energy Act of 2011. These four mining legislation are complemented by the Environmental Management Act of 1996 [13].

The Mines and Minerals Act (MMA) [12] defines the rules under which players in the minerals sector conduct business. It also outlines the rights, duties and obligations of government and of the exploration and mining investors as well as the applicable restrictions. For instance, section 37 (3) (h) of the MM Act [12] requires an application for the granting of the mining license to be accompanied by a statement giving particulars of the programme of proposed mining operations including a statement of proposals for the prevention of pollution, the treatment of wastes, the mining and for the minimization of the effects of mining on surface water and groundwater and on adjoining or neighbouring lands among other proposal statements. This Act provision is in addition to the Act provisions, with respect to the protection of the environment, contained under sections $94 \& 95$ of the Act that have been outlined above.

In addition to the mining legislative Acts, the working conditions in the Mining sector workplaces, like in any other employment workplace establishments, are specifically regulated by the country's labour legislative Acts which include the following: Labour Relations Act (LRA) No. 16 of 1996 [14]; Occupation Safety, Health and Welfare Act (OSHWA) No. 21 of 1997 [15]; Employment Act (EA) No. 6 of 2000 [16]; Workers Compensation Act (WCA) No. 7 of 2000 [17] and the Pension Act (PA) No. 11 of 2011 [18].

In brief, the Labour Relations Act of 1996 [14] is a law to promote sound labour relations through the protection and promotion of freedom of association, the encouragement of effective collective bargaining and the promotion of orderly and expeditious dispute settlement, conducive to social justice and economic development; the Occupation Safety, Health and Welfare Act of 1997 [15] is law that provides for the roles and responsibilities to be fulfilled by employers and employees as well as by all other relevant stakeholders involved in the safeguard of OSH workplace issues; the Employment Act of 2000 [16] is a law to establish, reinforce and regulate minimum standards of employment with the purpose of ensuring equity necessary for enhancing industrial peace, accelerated economic growth and social justice; the Workers Compensation Act of 2000 [17] is a law to provide for compensation for injuries suffered or diseases contracted by workers in the course of their employment or for death resulting from such injuries or diseases, to provide for the establishment and administration of a Workers' Compensation Fund; and the Pension Act of 2011 [18], is a law that provides for mandatory pension in Malawi whereby every employer in Malawi will be obliged to make provision for pension for his/her employees.

\section{Kaziwiziwi Coal Mining Company}

Kaziwiziwi coal mines limited started its operations in 1985 under the proprietorship of Mineral Investment and Development Corporation (MIDCOR) - a government owned company [5]. Kaziwiziwi mine was Malawi's first 
commercial coal mine to be opened before the opening of Mchenga coal mine in 1987 [5,19]. The mine is located within the livingstonia coal field in Rumphi district in the Northern region of Malawi. Overall, the whole livingstonia coal field has probable reserves of 2-5 million tons and proven reserves of 4 million tons of coal with ash content of $17 \%$, sulphur content of $0.5 \%$ and calorific value of $6.800 \mathrm{kcal} / \mathrm{kg}$ [8, 20]. Specifically the mine is located in Kambuzikaliwa village in Traditional Authority Kachulu covering an approximate area of 10.2 $\mathrm{km}^{2}$. The mining company conducted its operations for the first 5 years before it got closed in 1990 for 12 years. Finally, the company was opened in 2002 under the new proprietorship of a private owned business investor of Australian origin, Mr Axel E. Oberem, who owns the company to date.

Kaziwiziwi coal mining company started with four underground labourintensive long-wall faces (the mine bases) from where coal was loaded directly into trucks for transportation to customers. At that time, they were no facilities to clean or size the coal until 1987, when screening and sizing facilities were installed and used. Kaziwiziwi coal mines are currently producing on average 65.45 metric tons of coal per month. With this current production, there is a 162 $\%$ increase in coal production compared to an average monthly production of 25 metric tons during the first 5 years of its operations. At full capacity, the mining company can produce an average of 2,100 metric tons of coal per month from within its sized location. The coal at Kaziwiziwi has good calorific value and an ash content averaging less than $15 \%$ [19].

\section{Mchenga Coal Mining Company}

Mchenga coal mines limited (MCM) is currently the second largest mining company in Malawi after the temporary suspended uranium mining company in Karonga. MCML started its operations in 1987 again under the proprietorship of MIDCOR. The mine is located in the south east corner of the $90 \mathrm{~km} 2$ Livingstonia coal field in Rumphi district in the Northern region of Malawi. Specifically, the mine is located in Chiguliro village in Traditional Authority Njikula covering an approximate area of $17.5 \mathrm{~km}^{2}$. For 12 years, until 1999, the mining company was still a government owned company of which MIDCOR controlled the company for 8 years from 1987 to 1995 before transferring its control to Malawi Development Corporation (MDC) and Malawi Investment Development Bank (INDE-BANK) who controlled the company for 4 years from 1995 before it was privatized in 1999 to Coal Products Limited (CPL) company whose investors are owning the company to date.

MCML is currently producing on average 2,500 metric tons of coal per month. With this current production, there is a $55 \%$ decline in coal production compared to an average monthly production of 5,500 metric tons during the first 12 years of its operations. At full capacity, the mining company can produce an average of 7,500 metric tons of coal per month from within its sized location. CPL- Mchenga coal mines alone has probable reserves of about 1.5 million tons of coal with ash content of $17 \%$, a sulphur content of $0.5 \%$ and a calorific value of $6.8 \mathrm{kcal} / \mathrm{kg}[20]$. 


\section{Results and Discussion}

\section{Mining Activities and Workforce at Mchenga and Kaziwiziwi Mines}

Different mining activities are being undertaken at MCM and Kaziwiziwi coal mines workplaces and these are: supporting the mines; coal extraction/drilling; coal shunting and transportation from the mines to crushers; coal crushing and processing; coal sorting/screening, sizing and loading to customers as well as maintenance of equipments (engineering maintenance work) and services i.e. road constructions within the mining premises - road networks. All these workplace technical mining activities are, in addition to the administrative and managerial activities, undertaken at the mining workplaces of Mchenga and Kaziwiziwi coal mines.

The activities are being undertaken by various company employees in different work sections which constitute a total workforce of 252 employees (for MCML) and 241 (for Kaziwiziwi coal mines Ltd) as at July, $31^{\text {st }} 2014$, according to the companies' interviewed human resource officers. This means that the two coal mining companies, still use labour-intensive to carry out their operations as contrasted to use of machines i.e. mechanization. Note that almost all Malawi's mining companies are using labour-intensive technology thus the mining working conditions remain an issue of concern within the sector.

Both open cast and underground mining are the two mining methods used at the two mining companies. There are various names of mines or sections described as mining bases such as Base 2 (West Mine); Base 5 (East mine); Base 7 (Lutete mine); Base 10 (Chombe) and Vipungu as at MCML and Mine section 1 (MS1) and Mine section 18 (MS18) at Kaziwiziwi coal mines. The deepest mine at MCM goes to as far as 50 meters deep while at Kaziwiziwi, it goes as far as 45 metres deep from the top ground surface. The Shaft and Adit machines are used to deliver workers into and out of the underground mines.

\section{Corporate Social Responsibilities by Mchenga and Kaziwiziwi Companies}

According to the questionnaires administered to the two companies' authorities, the Mine Managers, the companies have done several corporate social responsibility interventions for the benefit of their workers and the communities around. These interventions include construction and provision of transportation and medical facility services. Table 1 shows construction activities done by the two companies under each of the named traditional leader's jurisdiction. 
Table 1: Implemented Corporate Social Responsibility Interventions

\begin{tabular}{|c|c|c|}
\hline \multicolumn{2}{|c|}{ MCHENGA COAL MINES LTD } & \multirow{2}{*}{$\begin{array}{l}\text { KAZIWIZIWI COAL MINES LTD } \\
\begin{array}{l}\text { Activities undertaken or to be } \\
\text { undertaken }\end{array}\end{array}$} \\
\hline $\begin{array}{l}\text { Name } \\
\text { Trad. } \\
\text { leader }\end{array}$ & & \\
\hline & $\begin{array}{l}\text { lenga primary school where } 1 \text { school block } \\
\text { toilets; football and netball playing fields; } 5 \\
\text { hers' houses; school head teacher's office } \\
\text { e been constructed } \\
\text { se for late chief Chiguliro where door } \\
\text { tters; door frames and window frames were } \\
\text { vided. Such facilities are being used to date } \\
\text { he current chief. } \\
\text { structed water pipeline in Jailos village } \\
\end{array}$ & \multirow{4}{*}{$\begin{array}{l}\text { - The company is supplying the community } \\
\text { - Tith clean treated water } \\
\text { - The company has a clinic that helps the } \\
\text { - Built and maintains school blocks at } \\
\text { Kaziwiziwi and Phoka government primary } \\
\text { schools } \\
\text { - The company fixes/maintains Rumphi- } \\
\text { Livingstonia road from Livingstonia to Lura } \\
\text { - The company sends learners to colleges and } \\
\text { helps drivers and operators get/acquire } \\
\text { licenses } \\
\text { - The company helps the community chiefs as } \\
\text { one way of strengthening the relationship } \\
\text { with the company } \\
\text { - The company is supplying free electricity for } \\
\text { the compound } \\
\text { The company constructed workers' hostels at } \\
\text { the mining site }\end{array}$} \\
\hline & da primary school and football playing & \\
\hline$\&$ & $\begin{array}{l}-\mathrm{Ul}_{\mathrm{l}} \\
\mathrm{Su} \\
\mathrm{Ja}\end{array}$ & \\
\hline A Chief & $\begin{array}{l}\text { - } \mathrm{Co} \\
-\mathrm{Ja} \\
-\mathrm{Cl} \\
\text { - } \mathrm{As} \\
\mathrm{cer}\end{array}$ & \\
\hline & $\begin{array}{l}\text { STA Kachulu with tobacco bailing } \\
\text { og and filling new doors and window } \\
\text { or STA Kachulu's house } \\
\text { cted water pipeline for chief Mpeta } \\
\text { cted Malowera bridge near Phoka court } \\
\text { achers' houses at Mnonono primary } \\
\text { r chief Mwaphoka }\end{array}$ & \multirow{3}{*}{$\begin{array}{l}\text { - Helps in the management of Kaziwiziwi } \\
\text { primary school. At the time of inception, the } \\
\text { school was a junior primary school with only } \\
3 \text { classes, } 1 \text { to } 3 \text {. Currently, the school has } \\
\text { been upgraded to std. } 7 \text { after the company } \\
\text { owners constructed a permanent school } \\
\text { block. The company pays full salaries every } \\
\text { month for } 3 \text { school teachers with salaries } \\
\text { ranging from Mk24,310 to Mk37,180.00 } \\
\text { Constructed a Dam that generates electricity } \\
\text { for use at the mine and by the surrounding } \\
\text { community. The Dam also acts as a learning } \\
\text { tool to educate local staff in the field of } \\
\text { engineering and maintenance and/or } \\
\text { sustainability jobs. }\end{array}$} \\
\hline & & \\
\hline & $\begin{array}{l}\text { free medical attention and drugs to } \\
\text { routine construction jobs to the } \\
\text { ling communities }\end{array}$ & \\
\hline
\end{tabular}

Source: Primary data collected by author of this paper.

The mining legislative framework has shown that the MMA of 1981 is being complemented by the EMA of 1996. However, to some extent, the two Acts do not complement each other by way of their provisions. For example, the EMA provides, as a mandate, for the mining company to conduct the environmental 
impact assessment (EIA) as a prerequisite requirement, among others, to be issued with a mining license but the MMA does not provide, as a mandate, for the licensed mining company to mandatory implement the EIA findings that may form as part of the recommended action points (the environmental impact mitigation measures) for the company to help address the mining environmental associated problems. This gap in the Malawi mining sector laws has resulted into incompatible implementation of corporate social responsibility interventions by the mining companies. For instance, table 1 shows several CSR interventions being undertaken by Mchenga and Kaziwiziwi coal mining companies for their workplaces' surrounding communities but the interventions are still being perceived by both the companies' employees and the surrounding community members as inadequate. To this effect, the two companies' authorities are failing to competently and confidently demonstrate to their employees and community members on whether they are doing enough or not for them due to lack of CSR benchmarks in the mining sector laws. It may be true that in the absence of clearly spelt CSR benchmarks or interventions in the MMA, the mining company may end up constructing several houses, for example, for the chiefs in the surroundings of the mining workplaces as is evident in table 1 , but such assistance may not be for the benefit of the majority community members at large hence defeats the whole purpose of environmental impact mitigation measures. Does the construction of chiefs' houses or assisting some individuals with the tobacco bailing jacks really form as part of the expected environmental impact mitigation measures? Such is one question that would not have arisen if the two mining sector laws had clear complementary provisions in respect of the EIA and CSR interventions. It is therefore proper to recommend that the two complementary mining laws of EMA and MMA should be reviewed to contain complementary provisions in respect of the EIA and CSR to the effect that CSR interventions or benchmarks/standards by the licensed mining companies should be made mandatory and be clearly spelt out in a form of schedule for easy implementation by the licensed mining companies and for easy monitoring and evaluation by the mining community members and the government. This will have a further impact of minimizing the workers' and community members' over expectations on what the licensed mining companies would be legally required to do for the communities and hence reduce some disputes both labour disputes and non labour disputes, a situation that is currently more pronounced at the two coal mining companies understudy which is also true in almost every other mining sector workplaces in the country.

\section{Working Conditions}

\section{Summary of prevailing Workers' problems at Mchenga and Kaziwiziwi Coal Mines}

Focus group discussions with employees' representatives of the two mining companies, contents of the 2013 workers' petitions to Rumphi District Commissioner and Labour office, findings of the 2013 survey conducted by a consortium of CCAP Livingstonia Synod-Church and Society programme (CSP) and CCJP of the Karonga Catholic Diocese, and labour disputes settlement reports maintained at Rumphi labour office, together reveal a common set of working problems faced by workers at the two coal mining companies of Mchenga 
and Kaziwiziwi in Rumphi district. The problems include the following among others: low and/or underpayments of salaries/wages or unfair or unequal distribution or treatment of salaries/wages in respect of employees on probationary period; inadequate or irregular compensation moneys (i.e. irregular or insufficient compensation for loss of land and livelihood, low workers compensation payments to injured or dead employees, reduced/deductable of compensation moneys and long outstanding/delayed compensation money to be payable; unfair dismissals/terminations or unprocedural retrenchments/redundancy of workers from work; long working hours (i.e. some workers 'forced' to work for more than 8 hours per day without overtime wages) and harsh working environment yet no risk or little underground work allowances (for instance, $5 \%$ of one's monthly basic salary is paid by Mchenga Coal Mines Ltd as underground work allowance); unclear employment contracts or forms (local workers put on temporary basis until he or she sustains injury is when the worker is put on permanent basis and many workers employed on casual work basis throughout e.g. 108 were casual workers at MCM Ltd out of a 361 total workforce in September 2008); corrupt recruitment/employment process i.e. allegations for employers to demand sex favours from women for employment (sexual harassment) and/or demand for money or reared animals (pigs, chickens, goats etc) from men; deduction of workers' salaries or wages while on sick leave, put on unpaid leave for those hospital admitted employees or end/terminate their employment contract; absence or inadequate OSH protective wears and safety measures i.e. provision of worn-out protective wears to workers; unproportional/too much workload (Mugwazo) for some mine underground workers i.e. mine trammers are required to carry 90 wheelbarrows of coal for a distance of 2 to $3 \mathrm{~km}$ during an $8 \mathrm{hr}$ shift work schedule per day, failure of which, the worker is marked absent despite having carried some number of coal wheelbarrows but less than the required 90 (in some instances, trammers are given a target to carry 102 coal wheel barrows for a distance of 261 metres during an 8 hr shift work schedule per day or 90,70 or 65 wheelbarrows per day with increased tramming distance); absence of workers' organizations (i.e. the trade unions) at Kaziwiziwi coal mines Ltd due to threats by management members (employers); absence of mandatory pension schemes for employees and unacceptable control of workers' pension contributions by MCM Ltd Directors; pollution and environmental degradation problems i.e. poor water and sanitation, air/water pollution and less workers' toilets at Kaziwiziwi coal mines and lastly inadequate Corporate Social Responsibility (CSR) activities (i.e. no teachers' houses, poor classroom blocks, no maize mill facility, poor welfare for workers e.g. no funeral assistance for death of workers' relatives even a child, lack of medical facility such as health clinics. Now what is the truth about each of the reported workers' problems at the two mining companies? The next paragraphs before the concluding remarks discuss this question.

\section{Salaries and Wages Condition}

Salaries and wages condition is one of the major working conditions that concern every workplace establishment in the employment sphere. They have direct impact on the living standards of the working population. For instance, salaries or wages drive consumption preferences and investments decisions that every salaried individual can make. Favourable consumption preferences and 
meaningful investments are requirements for the improved living standards of workers [21] which in turn can bring about the country's economic growth.

From the analysis results of table 2, it can be seen that the condition of salaries or wages in the two mining workplaces are generally poor.

Table 2: Employees' Monthly Salary/Wage ranges at Mchenga and Kaziwiziwi Companies as in April, 2014 in Malawi Kwacha.

\begin{tabular}{|c|c|c|c|c|c|c|}
\hline \multirow[t]{2}{*}{ Employee Category } & \multicolumn{3}{|c|}{ Mchenga Coal Mines Ltd } & \multicolumn{3}{|c|}{ Kaziwiziwi Coal Mines Ltd } \\
\hline & $\begin{array}{l}\text { Starting } \\
\text { Wage }\end{array}$ & $\begin{array}{l}\text { Maximum } \\
\text { Wage }\end{array}$ & $\begin{array}{l}\text { Frequ } \\
\text { ency }\end{array}$ & $\begin{array}{l}\text { Starting } \\
\text { Wage }\end{array}$ & $\begin{array}{l}\text { Maximum } \\
\text { Wage }\end{array}$ & $\begin{array}{l}\text { Frequ } \\
\text { ency }\end{array}$ \\
\hline Sorters, Checkers & $17,500.00$ & 17500.00 & 10 & $12,415.00$ & $12,415.00$ & 31 \\
\hline Mechanics & $44,948.40$ & $44,948.40$ & 2 & $25,000.00$ & $45,500.00$ & 3 \\
\hline Plant operators & $33,750.00$ & $33,750.00$ & 2 & $19,500.00$ & $19,500.00$ & 3 \\
\hline Compressor attendant & $21,302.50$ & $21,302.50$ & 13 & $12,415.00$ & $12,415.00$ & 2 \\
\hline Mechanical foremen & $80,000.00$ & $80,000.00$ & 1 & $17,160.00$ & $17,160.00$ & 2 \\
\hline Safety \& Environmental officers & $17,540.00$ & $20,196.25$ & 6 & $12,415.00$ & $12,415.00$ & 1 \\
\hline Shift bosses & $25,003.75$ & $25,003.75$ & 9 & $18,590.00$ & $18,590.00$ & 4 \\
\hline Drillers & $21,286.00$ & $21,286.00$ & 22 & $15,500.00$ & $15,500.00$ & 22 \\
\hline Timbermen & $20,050.00$ & $20,050.00$ & 16 & $13,585.00$ & $13,585.00$ & 17 \\
\hline Trammers & $20,199.00$ & $20,199.00$ & 24 & $14,000.00$ & $14,000.00$ & 70 \\
\hline Security guards & $17,540.00$ & $17,540.00$ & 54 & $12,415.00$ & $12,415.00$ & 10 \\
\hline Drivers & $25,500.00$ & $31,250.00$ & 4 & $25,740.00$ & $28,000.00$ & 3 \\
\hline Mine captain & $36,875.00$ & $36,875.00$ & 4 & $28,600.00$ & $68,640.00$ & 3 \\
\hline Mine manager & - & - & - & $195,000.00$ & $195,000.00$ & 1 \\
\hline Mine cashiers & $48,000.00$ & $48,000.00$ & 1 & $65,000.00$ & $65,000.00$ & 1 \\
\hline Government minimum wage rate & $16,530.00$ & open ended & - & $16,530.00$ & open ended & - \\
\hline Modal range with more workers & & & 54 & & & 70 \\
\hline
\end{tabular}

Source: Primary data collected by author of this paper.

Table notes: The average rate for US Dollar (USD) to Malawi Kwacha (MWK) as in April 2014 was 1 USD = $391.80 \mathrm{MWK}$ (visit: USD/MWK exchange rate history page). At the time of conducting this research in 2014, Government minimum wage rate per 30 day month was Mk16, 530.00 (US\$42.19), that is, Mk551.00 (US\$1.41) per work day (Malawi Government, Notice No 57 of 2013, gazetted Minimum Employment Wage Order).

Four aspects about salaries and/or wages condition can be explained from table 2. First, there is underpayment of wages which is more pronounced with respect to Kaziwiziwi coal mines. For instance, the monthly wages of Mk12, 415.00 (US\$31.69), Mk14, 000.00 (US\$35.73) and Mk15, 500.00 (US\$38.28), are below the required government monthly minimum wage rate of $\mathrm{Mk} 16,530.00$ (US\$42.19) (Malawi Government, Notice No 57 of 2013, gazetted Minimum Employment Wage Order) by $25 \%, 15 \%$ and $6 \%$ respectively. Furthermore, the absence of wage progression for each work category in terms of starting and maximum wage amounts as is mainly the case with Mchenga coal mines Ltd can also imply the underpayments of wages despite the fact that all the company's starting monthly wage amounts (Mk17, 500.00 (US\$44.67)) are above the government monthly minimum wage rate equivalent. This would be true in cases where the shown starting monthly earnings include overtime payments as a result of the mining employees who are frequently engaged in overtime work. Second, there is generally low wage payments experienced in these two mines. The table 
shows most of the starting monthly wages which are of course in compliance with government wage rate being distributed close to the mandatory minimum wage rate of Mk16,530.00 per month. This wage distribution scenario shows low wage payments that may not be in line with the unit labour productivity in the mining sector. Third, the complete absence of wage progression practiced by Mchenga coal mines employers as well as partial absence of wage progression by Kaziwiziwi coal mines employers entails that there is no room for increased wage bargaining against each work category. With this work scenario, what would happen in terms of salary levels with respect to two company drillers with different years of work experience while serving for the same mining employers? Does this mean that employers of these two mining companies pay their three year experienced drilling worker, salary that is equal to the salary paid to their one year experienced drilling worker? Last, the table indicates commonly low wages for almost all those employee categories with relatively greater frequencies. This means that most employees of the two mining companies are paid low wages whereas only few employees are paid better (higher) wages. It is this salary/wage analysis that justifies that there are generally poor salary/wage condition experienced at the two mining companies of Mchenga and Kaziwiziwi in Rumphi district.

\section{Working Hours and Environment Conditions}

Working hours and environment is another major working conditional category that is of concern for every mining workplace establishment. Working hours refers to the total number of hours worked by each employee per each work day whereas working environment refers to the immediate work site surrounding influences such as space, light, rest time, temperature, location/position, and people just to mention but a few. The working environment for the miners has direct impact on the daily performance of the miners.

For the mining workers at Mchenga and Kaziwiziwi coal mines, the work modalities use the shift work schedule of 8 hour work shift of one week rotational duration as shown in table 3 .

Table 3: Shift Work Schedule and Rotational Duration

\begin{tabular}{|l|c|c|c|}
\hline Mining Company & $\begin{array}{c}\text { Shift Work } \\
\text { Schedule }\end{array}$ & $\begin{array}{c}\text { Work Hours } \\
\text { per day }\end{array}$ & $\begin{array}{c}\text { Rotational } \\
\text { Duration }\end{array}$ \\
\hline \multirow{3}{*}{ Mchenga Coal Mine } & 6 AM to 2 PM & 8 & 1 week \\
\cline { 2 - 4 } & 2 PM to $10 \mathrm{PM}$ & 8 & 1 week \\
\cline { 2 - 4 } & 10 PM to $6 \mathrm{AM}$ & 8 & 1 Week \\
\hline Kaziwiziwi Coal Mine & $6 \mathrm{AM}$ to $2 \mathrm{PM}$ & 8 & 1 week \\
\cline { 2 - 4 } & $7 \mathrm{AM}$ to $4 \mathrm{PM}$ & $\begin{array}{c}9 \text { with } 1 \mathrm{hr} \\
\text { lunch }\end{array}$ & 1 week \\
\cline { 2 - 4 } & $2 \mathrm{PM}$ to $10 \mathrm{PM}$ & 8 & 1 Week \\
\cline { 2 - 4 } & $10 \mathrm{PM}$ to $6 \mathrm{AM}$ & 8 & 1 Week \\
\hline
\end{tabular}

Table 3 indicates that the mine workers at the two mining companies work for 8 hours per day which is in compliance with labour laws that provide for the maximum 8 working hours per day by every worker. This means that working hours as a work condition at the two mining companies under study is deemed 
good. However, it could be bad whenever employees working for overtime hours are not paid overtime wages computed according to overtime types and rates prescribed by labour laws. For both Mchenga and Kaziwiziwi mines, all workers that were interviewed indicated that correct overtime wages are paid for the worked overtime hours.

On the other hand, the working environment was reported to be relatively harsh for workers at both Mchenga and Kaziwiziwi mines. A tour by the author of this paper into one of the deepest mine section of Mchenga coal mines Ltd reported unfavourable working environment in the underground mines which include inadequate light, loneliness, and heat, among others. In addition, a government Occupational Safety, Health and Welfare expert interviewed described the underground work environment as generally health hazardous citing a situation where one has to work in a confined space bound to affect the worker's work efficiency - ergonomics. With such work environment, an 8 hour work schedule may not be favourable on the part of workers. This could be complicated by the fact that any resting time utilized while at work in the underground mine may still not be of much relevant in a bit lonely working environment. Are these working hours in a week including overtime worked hours (on day-offs overtime) flexible enough to give workers opportunities to undertake other equally important endeavours for extra money such as socialization activities etc? The working hours condition is not really the problem but rather the work environment. Therefore a proposal for separate high wage rate for the underground mine workers and reduced work hours per day for such workers would be better and necessary. This would be better because high wage rate will help these workers to have increased or rather sufficient monthly earnings / income for their upkeep and hence reduce their tendencies of struggling to work even on Sundays with the aim to increase their pay instead will opt to rest, whereas the reduced work hours will help workers to be in a rather unfavourable work environment for a lesser period of time to allow for relaxation thereafter.

\section{Work Condition of Temporary and Casual Workers}

Temporary worker is an employee serving on probationary period pending confirmation on permanent basis or otherwise. Casual work is a short-lived work. It is a piece work (ganyu), the work without a lasting employment relationship (Oxford Dictionary). The Malawi employment Act defines piece work as work in terms of which the remuneration of employee (the casual worker) is based mainly on the quantity of work done.

In 2008 by September, Mchenga coal Mines company alone had a total of 108 casual workers out of 361 total workforce (interview with company HRO). This means that $30 \%$ of the company total workforce at that time was casual employees. Similarly Kaziwiziwi coal mining company also employs casual workers who are paid their wages every fortnight. Workers at the two coal mining companies argue that their employers' behaviour of adopting casual form of employment is one way of oppressing/victimizing employees. In their arguments, workers stated that:

There is a lot of employee victimization and discrimination here. Just imagine, many employees are employed to work as casual workers for many years until when they get injured is when they are given Mine Numbers by 
employers for fear of being penalized by labour laws (State authorities). Furthermore, there are some employees who have worked for more than one year without Mine Numbers - example Martin Mulenga, an MSCE holder has worked for one year and 3 months as a coal off-loader which we feel is a misuse of office.

This argument is contained in the worker's petition/strike notice letter copied to Rumphi district labour office in May 2012, in which workers at Mchenga coal Mines had vowed to go on strike or to have, the company Human Resource officer and her assistant removed from work immediately because of their unfair treatments over the workplace employees. Why employers find relief in employing casual workers rather than temporary or permanent employees? What is the position of casual work in respect of the country labour laws, and how protected is a casual worker? These are some of the crucial questions to be addressed with respect to their working condition of temporary and casual workers.

The employment of casual worker reduces employer's liability of paying compensation in case of injuries sustained by a worker while at work because casual workers are not defined as workers for the purpose of workers compensation (section 2 (a) of the WCA of 2000) [17]. However, a casual work is a legally acceptable form of employment contract in Malawi. It falls within a contract for a specific task such as piecework (ganyu) as implied from section 25 (2) (c) of the EA of 2000 [16]. Thus a casual worker, like any other employee, is entitled to wages/salaries as one right constituted within the employment relationship between an employer and employee. In addition, Pension Act of 2011 [18] covers the continuously employed casual labourers/workers for the purpose of mandatory pension contributions. In this regard, it is clear that casual workers are also protected as workers by the country labour laws. Most importantly, sections 26 (1); 41 (3) (d) and 43 of the EA of 2000 [16] once read and understood together imply that every casual worker through his/her worked aggregated portions of employment with the same employer is deemed to be a continuously employed worker for the time length equivalent to the sum of the aggregated portions. This, according to section 26 (1), means that a casual worker with an aggregate service length of more than 12 months for the same employer will have fit as a temporary employee to be confirmed a permanent employee or automatically to become a permanent employee by operation of law. Furthermore, it means that a casual worker who is working in bits/breaks of weeks or months for several weeks or months, will have his/her bits worked aggregated to make one length of service to be defined as his/her continuous employment period with the same employer.

\section{Work Condition of Non-payment, Low or Delayed Workers Compensation}

The work condition of low or delayed compensation or of non-payment of compensation at all happens at the two mining workplaces. For instance, data collected show that a number of compensation cases that were opened way back in 2004 or 2006 were settled in 2010 while some of them not paid until now. For instance, a total of 35 compensation cases reported by Mchenga coal mines company for processing in different years between 1999 and 2008 were settled (paid and closed) in July 2011 [22]. Similarly, the same report indicates relatively 
low ranges of compensation moneys paid for fatal cases (i.e. from minimum of Mk78, 720.00 to maximum of Mk357,343.14) during the period of 2006 to 2011. These are relatively smaller amounts when compared to the loss of someone's life. Whereas at Kaziwiziwi coal mines limited, the fatal case in 2013 that was settled with the maximum sum of compensation money attracted only Mk441, 000.00 which was in respect of late Golie Wachose. When discussing this work condition, the critical question to be asked therefore is: why low or delayed or non-payment of workers compensation?

The nature of the mining activities make workers prone to various forms of workplace injuries ranging from minor injuries due to crushes by small stones to serious injuries/accidents including fatal accidents. Most of such injuries can be avoided through use of protective wears such as hand gloves, eye goggles, head crush helmets etc while at work. While the employers of Mchenga and Kaziwiziwi coal mines struggle to comply with labour laws in respect of providing mine workers with adequate protective wears, some workers negligently ignore wearing protective wears while at work saying that they (the protective wears) delay, disturb or make them feel hot or uncomfortable etc. An interview with one of the mine worker at Kaziwiziwi stated that: "Zovala za pa ntchito zimatentha" meaning that protective wears make workers feel hot. However some of the workers argued that they do not want to use the protective wears because they are provided with worn out wears whereas the employers stated that workers are not given some more pairs of protective wears like the overalls to each worker at a time because workers sell out such materials to remain with one at a time. The behaviours of workers ignoring use of protective wears and that of undermining some company underground mining safety regulations (as indicated in box 2 below) are some possible ways of promoting the occurrence of workers' injuries at the mining workplaces. At one time, the Regional labour officer from Mzuzu labour office in the quest to find a lasting solution to the problem of workers' negligence to use protective wears ruled that:

Protective wear is provided once a year. Some employees use it while some do not. Our visiting team felt that providing protective wears once a year is not adequate. We recommended to management to provide one pair every 6 months (to avoid their selling of the same if two pairs are issued at once). Having noted that a number of employees deliberately ignore using protective wear we advised management to enforce usage of the same by coming up with certain conditions, for example, if one does not put on protective wear, one should be sent back home and be marked absent for that day.

In terms of reporting workers accidents to relevant authorities as required by law, the two mining companies' employers have improved for the past 10 years in complying by reporting their workplace accidents to labour offices for compensation soon they occur at their places of work. This is true as evidenced by a number of workers compensation case files that were found to be in progress at Rumphi labour office as well as those shown in office registers to have been settled and closed. The examined case files at labour offices were for workers from both Mchenga and Kaziwiziwi coal mining companies. For further reference on reported accidents, see the boxed text in the ( $\mathrm{S} 1$ Appendix) which is for a fatal accident report by Mchenga coal mining company that led into loss of life for one of the underground mine workers. 
A critical analysis of the fatal report in boxed text shows, however, that the report was not conclusive in respect of the company's investigating team to establish what really made the deceased worker to go to the place of his fate. Was it really the worker's negligence of safety rules or was it not the "call of nature" that might have driven him to that place in cases where toilets, for example, are not available within the underground mines or not in usable state? The investigators should have really interrogated the other workers on where do they go to respond to call of nature while working in the underground mines in cases of absent or non usable defecation facilities (toilets)10 in order to probe some more objective reasons that might have led the deceased into the place of his fate rather than just concluding that "Alex Songa disobeyed the standing safety regulations by going into a prohibited and barricaded area" as indicated in the fatal accident report. According to information collected during focus group discussions, toilet facilities are not available within the underground mines at both Mchenga and Kaziwiziwi coal mining companies. An interview with one the underground mine workers revealed that a toilet is at the top ground area of each mine base area and that the underground mine workers to respond to calls of nature do move out of the mines to the surface area to access toilet facilities. Furthermore, the interviewed underground workers were non committal to give more light on what would happen in cases where one's call of nature is abrupt due to somebody problems such as sicknesses or due to problems with the mine evacuating machines - the Adit shafts. The mine barricaded area is an area which has been mined out (left out) because coal to be extracted has been finished. The mine supporting pillars along the walls of such barricaded area are usually removed and the entry to such an area is usually closed/broked with barricades. With all such workplace environment, it is only if the real cause was to be established by the investigating team is when the correct possible solution to deal with workers of such behaviours would have been found and not just "to maintain barricades around prohibited areas; to continue safety meetings by Safety Supervisors; and to be taking disciplinary actions against those workers who do unsafe acts while in the underground mines, or elsewhere". Does this not mean that disciplinary actions will only be applicable for those that survive but what about those who die, shall they also be disciplined? If a solution is seen to be insufficient like this one suggested by Mchenga employers, it means that the real problem cause being proposed to be solved may not be correctly or effectively addressed.

Workers compensation is a stage process that begins from when the employer reports the worker's accident to a government labour office using a prescribed form labeled WC 1 (as Workers Compensation form number 1) as required by section 24 of the Workers Compensation Act, 2000 [17]. The process ends at the time when the injured worker's compensation is paid as per the guidelines prescribed in the law. Stage three of the process requires the injured worker to be assessed at the hospital to establish his/her degree of incapacitation following haleness of the injury. Whereas, for the dead worker, stage three process, awards an automatic $100 \%$ degree of incapacitation.

In the event that stage three process establishes a zero percent degree of incapacitation, there will be no compensation payable to the injured worker because zero percent assessment implies that the worker has not been incapacitated and that he/she will not suffer any incapacitation of any form due 
to his/her sustained injury unless doctors make mistakes in assessment of the worker. The zero percent factor once used into the workers' compensation formula, will result into zero kwacha as compensation amount. In this case, such a compensation case file is closed and the worker and the worker's employer informed accordingly. This constitutes a circumstance of no workers compensation payable for some reported cases at Mchenga or Kaziwiziwi coal mines. However, the non-payment of workers compensation can also happen at a workplace due to the employer's negligence to or deliberate plan not to report workers accidents to authorities for purpose of compensation, the behaviour that cannot be ruled out at the mining companies' workplaces.

Secondly, the problem of low compensation amounts is due to the formulas provided for under sections 7 (1) (a) and 8 (1) of the Workers Compensation Act, 2000 [17]. The formula use worker's average monthly basic pay at the time of injury and the assessed degree of incapacitation as the two multiplying factors. This means that a worker whose average monthly basic pay is relatively higher is bound to be paid a relatively higher compensation amounts than the other one and vice versa. The same scenario/implication applies to a worker with a relatively higher degree of incapacitation. Thirdly, for the delayed payment of workers compensation, it is necessary to note that a number of factors are at play. These are: delayed reporting of worker's accident to mandated authorities; inadequate or absence of the State workers compensation pool fund; inadequate capacity (i.e. personnel) to handle workers compensation processes on part of government and workers compensation process with lengthy involvements (of course this is so for purposes of checks and control). The latter three are usually the cases with respect to Mchenga and Kaziwiziwi coal mining companies.

\section{Workers' Organizations and their Freedom of Association}

Reports and documentary records sourced at the two company workplaces and those available at Rumphi district labour office indicate that workers at both Mchenga and Kaziwiziwi coal mines rarely formed or participated in workers' organizations such as in trade unions; in joint consultative committees (JCCs) among others between the years of 1985 to 1994 unlike during the periods after 1996 when the same documentary record sources show evidence of workers organizations' activities with more of them at Mchenga coal mines than at Kaziwiziwi.

The analysis and enquiry to find out why such status was the case, revealed that from 1985, the year Kaziwiziwi coal mine opened and/or 1987 (the year Mchenga coal mines opened) to 1994, Malawi was governed by a set of laws which were full of oppressive provisions on the part of employees [23] to the extent that they (the laws) did not provide for the active formation and operation of trade unions as well as allow for freedom of association. However, following the multiparty democracy in 1994 and the subsequent enactment of democratic labour legislative laws in 1996 and thereafter, (that provided for the formation of trade unions as one major form of workers' organizations and also granted workers freedom of association), the mining workers from the coal mining companies under study, started to engage in collective bargaining process with their employers through their formed unions and/or JCCs (as it became the case with workers of Mchenga coal mines Ltd - see table 4) as well as to demand their rights where necessary. 
As a result, of the establishment of JCCs at Mchenga coal mining company in 1996 followed by the establishment of the Building, Construction \& Civil Engineering Allied Workers Union of Malawi (BCCEAWUM) trade union in 2009, relationship between employers and employees at Mchenga coal Mines has been improving to the effect that a number of some past harsh described work conditions have improved for the betterment of workers. Some quotations and report extracts contained in box 2 are evident to demonstrate some improvements in conditions of work whereas table 4 shows how workers' organizations have helped or are helping towards the improvements of conditions of service at the mining companies' workplaces.

Table 4: Industrial Actions and Workers' Organizations' Engagements with Management

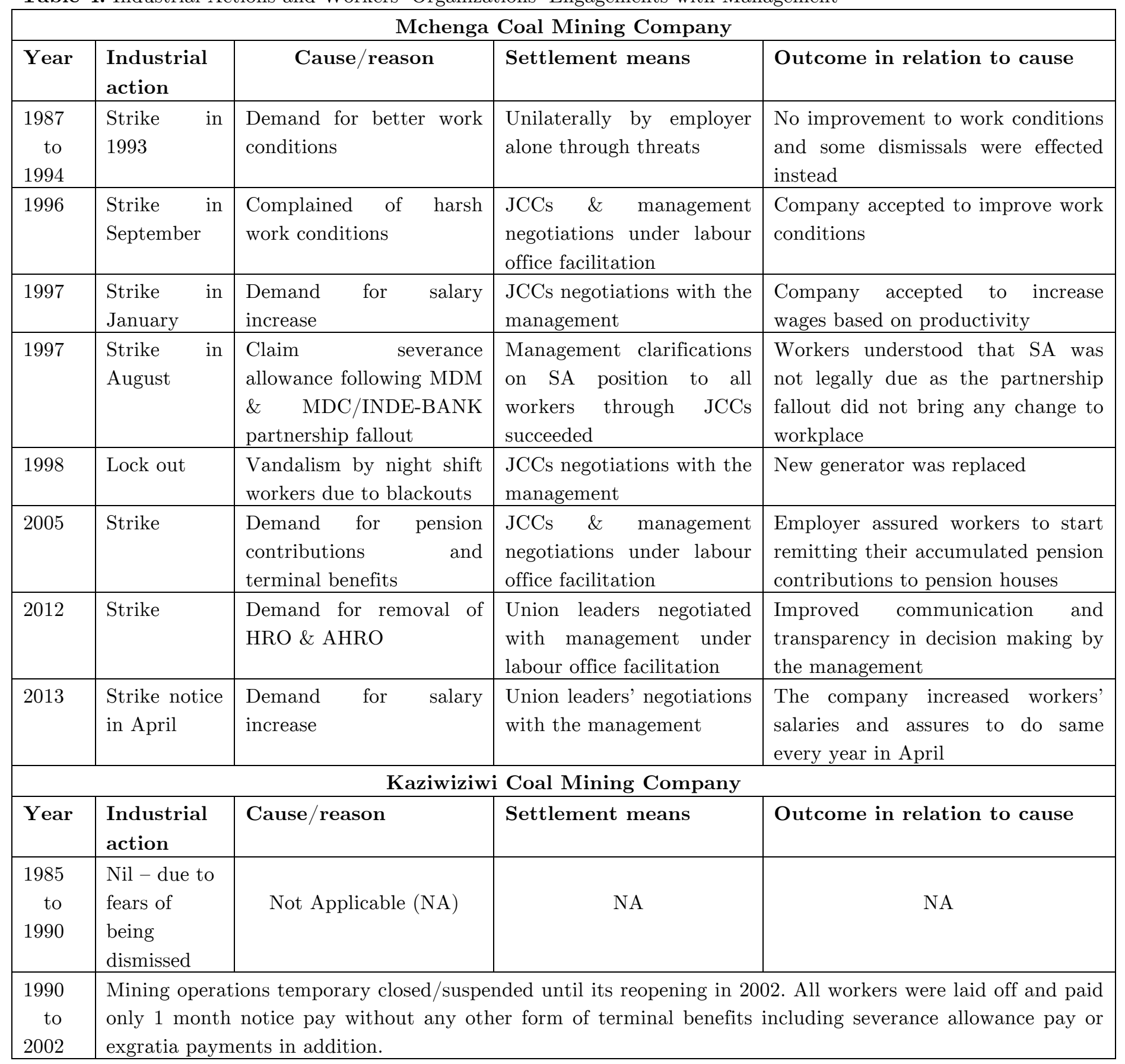




\begin{tabular}{|c|c|c|c|c|}
\hline 201 & $\begin{array}{l}\text { Petition by } \\
\text { non } \\
\text { employee } \\
\text { community } \\
\text { members \& } \\
\text { Strike notice }\end{array}$ & $\begin{array}{l}\text { Communities complained } \\
\text { of inadequate CSRs and } \\
\text { of improbable/inhuman } \\
\text { work conditions. Workers } \\
\text { demanded for increase of } \\
\text { salaries/wages. }\end{array}$ & $\begin{array}{l}\text { Labour officials mediated } \\
\text { the conflicts in company } \\
\text { with other government } \\
\text { officials i.e. Lands, Health } \\
\text { and Environmental and } \\
\text { Mining officers. }\end{array}$ & $\begin{array}{l}\text { Company accepted to improve work } \\
\text { conditions - immediately increased } \\
\text { monthly wages from Mk12, } 415 \text { to } \\
\text { Mk17,000 for the lowest earning } \\
\text { category of workers, just to mention } \\
\text { a few. }\end{array}$ \\
\hline
\end{tabular}

Table 4 shows that workers' organizations such as Joint Consultative Committees (JCCs) and/or trade unions were established and have been working at Mchenga coal mines since 1996 to date. On the other hand, similar structures (trade unions, workplace committees, employees/employer bargaining procedures) are not yet established at Kaziwiziwi coal mining company. The BCCEAWUM trade union was established at Mchenga coal mines in 2009. The union replaced JCCs that had been established at the mine in 1996. Both the JCCs and the Union leaders have been conducting enterprise collective bargaining negotiations at various levels and/or times with the management of the company. As a result, there are generally improved working conditions at Mchenga coal mines as compared to Kaziwiziwi coal mining company. For instance, table 2 shows higher wages with the lowest paid employee category receiving monthly wages (Mk17, 500.00) above the government minimum wage rate for Mchenga mine workers than for Kaziwiziwi mining company where the lowest paid employees receive monthly wages $(\mathrm{Mk} 12,415.00)$ below the government minimum wage rate which is underpayment of wages and hence non compliance with labour laws by the company employers. Secondly, occurrence of frequent industrial actions (strikes or lockouts) at Mchenga coal mines and not at Kaziwiziwi as shown in table 3, implies to some extent increased level of knowledge amongst workers on their working rights (labour laws), the situation that make workers exercise their right to strike and employers to lockout in cases where their workplace disputes remain unresolved. Kaziwiziwi workers might have not been staging industrial strikes either because of fear of being dismissed from employment hence their choice to suffer in silence or due to not being aware that striking is one of their rights to pursue in order to express their grievances to their employers. Workers' strikes besides their indication of poor workplace labour relations, they are also a sign of workers' and employers' engagements in enterprise level bargaining activities that are required by labour laws for future improvement of workplace labour relations. The capacitated mining sector communities following the CSOs' advocacy project works, started to present strike notices and petitions to the mining company authorities demanding improved working conditions towards the end of 2013. For Kaziwiziwi, the demands were compiled and signed by non workplace employees (not even acting as union leaders) some of whom were chairpersons of the Area Development Committees (ADCs) and of Village Development Committees (VDCs) drawn from the mining surrounding communities. The demands were a mixed up of things. They were those demands on corporate social responsibilities as well as those demands on workers' labour rights. Such presented demands left the mining company employers in a dilemma. The employers did not know which set of demands were to be addressed as workplace issues. Similarly, the petitioners too did not know on whether or not they were legally mandated to involve themselves in demanding labour rights on behalf of their working brothers and sisters (relatives) from the mining employers. But what is the position of the 
country labour legislative laws on who are legally supported to collectively engage with the mining companies' employers between the mining workplace employees and the non employee community members regarding the fight for labour rights (improved working conditions) and/or for the company CSR interventions?

The current labour legislative framework in Malawi is far much adequate and clear in respect of the protection of workers' rights with regard to workers'organisation and freedom of association while at work. For instance, sections 4 and 5 of the Labour Relations Act of 1996 [14] provide for freedom of association and rights of both trade unions as well as employers' organizations respectively. Specifically, section 4 gives every person (worker or employer) the right to freedom of association which includes freedom to establish and join organizations of one's own choosing. Whereas section 5 gives every worker or employer the right to take part in the formation, right to become a member of any federation of trade unions or employers' organizations and to participate in their organizations' lawful activities. In terms of employees' protection, section 6 (1) (b) of the same Act protects any employee not to be dismissed from work because of his or her trade union membership or participation in the formation of a trade union or in the union's lawful activities. Furthermore, on collective bargaining between employers and employees, sections 25 and 26 of the Labour Relations Act of 1996 [14] provide for both enterprise and sectoral level bargaining. Enterprise level bargaining refers to single workplace bargaining between a group of employees for one workplace and their workplace employer while the sectoral level bargaining refers to more than one workplace bargaining between a group of employees' representatives from various workplaces of one industry, say tobacco or tea or mining sector and the employers' representatives from the same respective sector through the employers' formed sectoral associations. These collective level bargaining processes are further regulated by section 31 of the same Act that provides that all parties (employees and employers) to the negotiation of a collective agreement must be able to bargain in good faith and to make every reasonable effort to conclude a collective agreement. Finally, the pre-strike conciliation procedures and strike or lockout procedures are provided for under sections 44 and 46 of the same Labour Relations Act14 respectively. These are the procedures that are directive guidelines for both the employees and employers to know what to do in their processes of attempting to resolve their labour disputes or attempting to stage an industrial strike or lockout. With these few cited provisions, it shows that labour laws are adequate and clear with respect to workers' organizations and freedom of association. Furthermore, it is clear that the laws require workplace workers' themselves or their union organizations and not the non workplace employees to enter into collective bargaining with their employers fighting for their labour rights at a place of work.

While the enterprise level collective bargaining activities between the employer's management team members and the employees' union leaders have brought about improved communication between the management team members (employers) and employees; minimized unnecessary work dismissals among other positive things at Mchenga coal mines workplace as demonstrated by some of the cited quotes and report extracts shown in box 2, the contrary is the case at Kaziwiziwi coal mines workplace which is still without the required workers' and employers' bargaining structures. For instance, unfair dismissals still prevail at 
Kaziwiziwi according to an interview with one of the workers who stated that "the Mine General Manager dismisses workers while at the work site without providing them with right to be heard".

The absence of collective bargaining activities between workers and their employers at Kaziwiziwi coal mining company despite the presence of adequate labour laws; the overall mixed up demands by the communities including workers for improved working conditions in the mining sector; and the analysis from table 4 , together, suggest the prevalence of the following issues that require attention by the relevant authorities: inadequate enforcement capacity by government on the existing laws i.e. absence of frequent routine labour inspections including $\mathrm{OSH} /$ factory labour inspections as well as absence of the routine mining inspections; ineffective and/or insufficient trade union activities in the mining sector; enterprise (workplace) level collective bargaining activities are effective towards the improvement of working conditions at a place of work; and lack of adequate knowledge on labour laws by workplace parties especially employees regarding their working rights as employees; ignorance, amongst the mining sector community members including workers, on the position of corporate social responsibility in Malawi and on what CSR interventions are required to be undertaken by the mining companies for the benefit of the surrounding communities.

While it may be necessary for the non employee community members to demand for the CSR interventions and for improved working conditions on behalf of their employed brothers and sisters for the mining companies' employers to undertake, it is strongly advisable that it should only be the mining workplaces' employees or their affiliated trade unions that should be in a legal position to demand for their improved working conditions from their employers. The non employee community members who do not have any right to demand for improved working conditions on behalf of their employed relatives can only participate in demands for the mining companies' CSR interventions which should be reasonable and realistic demands considering that the country does not yet have the prescribed mandatory standards as CSR interventions by the mining companies in the existing mining sector legislative frameworks. Why are reasonable and realistic demands necessary and why proper for only employees to demand for improved working conditions? This is because it is only those labour rights demands by the workplace employees who are party to the respective workplace employers that can be enforced by the operation of labour laws and not those by the non employees who are not workplace bonafide parties. If it is due to fears of being dismissed from work or due to power imbalances that make the bonafide workplace employees unable to fight for their labour rights and instead opt to use their non employed brothers or sisters, then it is recommended that such employees should attempt to achieve their goal objectives through use of their affiliated trade unions or their concerted collective efforts through collective bargaining procedures with their employers.

It should be noted that only the reasonable and realistic demands are necessary for stimulating continued developments into the area arising as a result of the sustained mining operations in such areas. Some unrealistic / unreasonable demands can create unfavourable investment environment for the mining companies that may end up closing their mining operations. The closure of the mining operations can result into immediate loss of jobs; loss of the ongoing little 
CSR interventions in the area such as road maintenances, health clinic services and water/electricity provision services; and in the long run, results into general underdevelopment of the mining respective areas and the country as a whole through the decrease in the country's GDP as a result of the closed mining operational activities. The recent massive job cuts following the suspension of Kayerekera uranium mining operations in Karonga is one case for reference. Similarly, it is also the reasonable and realistic labour rights demands that can enable the employers to manage any progressive improvements in conditions of service for workers such as increased salaries among others without necessarily compromising the company's profits for sustainability.

In respect of the above discussed issues, it is therefore proper to draw the following policy recommendations for actions by the appropriate authorities. First, there is need for the government to improve the enforcement of the existing laws and regulation of the mining sector activities through the government's core businesses of labour and mining inspection activities. Second, there is need for revision of the archaic Mines and Minerals Act of 1981 [12] along with its policies and also for the government to define and legalize standard interventions/issues to constitute the corporate social responsibilities in Malawi. Third, there is need for the CSOs to be conclusive in their complementary roles to government works. For instance, CSOs need to be focused in formulating their work objectives that should help achieve the balanced results out of their complementary roles. They should not deliver to enable the mining sector community members to embark into some unreasonable or unrealistic demands that may not be well supported by the country laws. Most importantly, CSOs should be concluding their complementary role through use of well defined strategies or approaches involving or engaging government technical officials while delivering their advocacy activities to the communities for the communities to be sensitized on both positive and negative aspects of fighting for improved working conditions so that the negative impacts that are mostly not covered by the CSOs should also be adequately covered to enable concerned citizens including employees to make balanced decisions. This, in addition, would enable government technical officials to provide policy directions and quality control regarding the laws regulating the interactions between the mining workplace parties in the event that the CSOs (CCJPs) officials lack adequate advocacy capacity skills as observed by Tilitonse PEA report of 2013 [4]. Finally, there is need to promote the establishment of effective workplace industrial relations systems (structures) such as the safety workplace committees, JCCs or the trade unions and the Industrial Tripartite Councils (as provided for under section 27 of the LRA of 1996 [14]) for the purpose of conducting both the enterprise and sectoral levels of collecting bargaining activities. The established mining employers' sectoral associations for the purpose of the mining sector collective bargaining would be very much beneficial in the event that some workplace mining employees are unable to form their own workplace collective bargaining structures with their employers as has been evident with workers of Kaziwiziwi coal Mining Company. The employers' and employees' sectoral associations together with the industrial tripartite councils established for the Tea Associated Companies in Malawi have proved to be working towards the improvement of the working conditions in the Tea growing industry in Malawi [24]. 


\section{Conclusion and Recommendations}

First, the paper has established that the working conditions experienced at the two mining companies of Mchenga and Kaziwiziwi in Rumphi district are generally poor to the effect that low salaries/wages are paid; the working environment in the underground mines is unfavourable; and that low / delayed compensation is being experienced. Furthermore, the paper has discussed and shown that the workers' organizations and their activities in the mining sector may be the effective tools for the improved working conditions among other workplace structures and as such it has been recommended that every workplace establishments including the mining sector workplaces should promote for the establishment of the workplace industrial relations structures as required by the country's labour laws for the purposes of collective bargaining activities.

Second, it has been shown that the MMA of 1981 and the EMA of 1996 which complement each other have some incompatible complementary provisions [25] in the sense that the EMA provides, as a mandate, for the mining company to conduct the environmental impact assessment (EIA) as a prerequisite requirement, among others, to be issued with a mining license whereas the MMA does not provide, as a mandate, for the licensed mining company to mandatory implement the EIA findings that may form as part of the environmental impact mitigation measures for the company to help address the mining environmental associated problems. It has therefore been recommended that the two complementary mining laws of EMA and MMA should be reviewed to contain complementary provisions in respect of the EIA and CSR to the effect that CSR interventions or benchmarks/standards by the licensed mining companies should be made mandatory and be clearly spelt out in a form of schedule for easy implementation by the licensed mining companies and for easy monitoring and evaluation by the mining community members and the government. This once done, will have a further impact of minimizing the workers' and community members' over expectations on what the licensed mining companies would be legally required to do for the communities and hence reduce some disputes both workplace labour disputes and non labour disputes [26].

Third, the paper has observed that while it is necessary for the non employee community members to demand for the CSR interventions and for improved working conditions on behalf of their employed brothers and sisters for the mining companies' employers to undertake, the paper has strongly advised that it should only be the mining workplaces' employees or their affiliated trade unions that should be in a legal position to demand for their improved working conditions from their employers and that the non employee community members who do not have any right to demand for improved working conditions on behalf of their employed relatives should only participate, where necessary, in demands for the mining companies' CSR interventions which should be reasonable and realistic demands considering that the country does not yet have the prescribed mandatory standards as CSR interventions by the mining companies in the existing mining sector legislative frameworks. This would be good and proper because only those labour rights demands filed by the workplace employees as party to the respective workplace employers can be enforced according to the current country labour laws and not those by the non employees who are not 
workplace parties. On this note, the paper has also recommended that employees should attempt to achieve their goal objectives of improved conditions of service through use of their affiliated trade unions or their concerted collective efforts through collective bargaining procedures with their employers in cases of power imbalances that may make certain workplace employees unable to fight for their labour rights while discouraging the unreasonable and unrealistic demands that may be detrimental towards the country's investment environment.

Finally, the paper on overall concludes by drawing the following policy recommendations based on the above findings: the government should improve the enforcement of the existing laws and regulation of the mining sector activities through the improvement of its core businesses of labour and mining inspection activities [26,27]; the government should revise the archaic Mines and Minerals Act of 1981 along with its policies and also to define and legalize standard interventions to constitute the corporate social responsibilities in Malawi; the CSOs should be conclusive in their complementary roles to government works (i.e. CSOs should be focused in formulating their work objectives that should help achieve the balanced results out of their complementary roles. They should be concluding their complementary role through use of well defined approaches engaging government technical officials while delivering their advocacy activities to the communities for the communities to be sensitized on both positive and negative aspects of fighting for improved working conditions so that the negative impacts that are mostly not covered by the CSOs should also be adequately covered to enable concerned citizens including employees to make balanced decisions; and that all the three industrial relations key partners (i.e. the trade unions, the employers organizations and the government) should work together to promote the establishment of effective workplace industrial relations systems (structures) such as the safety workplace committees, JCCs or the trade unions and the industrial tripartite councils for the purpose of conducting both the enterprise and sectoral levels of collecting bargaining activities.

\section{Acknowledgments}

In the first place, I would like to express my sincere gratitude to my academic referees, Professor Lewis Dzimbiri and Associate Professor Rhoda Bakuwa for their encouragement words for me to continue on researching in attempt to explore possible scientific solutions to various problems within the field of my expertese - The Industrial/Labour relations. I thank them for their positive comments and feedback regarding my first preliminary draft of this paper which enabled me to progress smoothly.

Secondly, I would like to thank and acknowledge my district team workmates who includes Frank Mkandawire, the Director of Planning and Development; Ethel Kamba, the District environmental officer and other various contributors, who rendered their assistance in various capacities to me in the course of planning and collecting data for this paper. Special thanks should also go to all the study respondents including owners of the two companies under study for answering my questionnaires timely and to Mr W. Msukwa, the Deputy Labour Commissioner for the trouble he went through in providing additional key information as well as helping me get relevant reference materials. 
Finally, sincere gratitude and thanks to my beloved wife, Modesta, for her perseverance and endurance during my engagements while analyzing and writing report of this paper. May God bless all of them!

\section{References}

1. Malawi Government. National Mines and Minerals Policy. Lilongwe: Ministry of Natural Resources, Energy and Environment; 2013. Malawi Government Publishing services. Available from: www.malawi.gov.mw/

2. Kazakhstan. King of the Producers in Uranium: A Supplement to the Mining Journal. Mining Journal [serial on the Internet]. 2011 [cited 2014 April 1]. Available from: Paladin AustralianUraniumPublications.

3. Malawi Government. National Mines and Minerals Policy. Lilongwe: Ministry of Natural Resources, Energy and Environment; 2007. Malawi Government Publishing services. Available from: www.malawi.gov.mw/

4. Tilitonse. Political Economy Analysis of Mining in Malawi: Final Report. Lilongwe: Department for International Development (DFID); 2013.

5. Yager TR. The Mineral Industry of Malawi. In: Malawi 2010 Minerals Yearbook. New York: Geological Survey Department of the Interior; 2010.

6. Malawi Growth Development Strategy (MGDS II). Adopted report. Lilongwe: Malawi Government Press; 2012.

7. Malawi Economic Recovery Plan (MERP). Final draft report. Lilongwe: Malawi Government Press; 2012.

8. Annual Economic Report. Published report. Lilongwe: Malawi Government Publishing services; 2012 .

9. United Nations. The Role of Governments in Promoting Corporate Responsibility and Private Sector Engagement in Development. New York: Bertelsmann Stiftung; 2010.

10. Organisation for Economic Co-operation and Development (OECD). Promoting Pro-Poor Growth: Employment and Social Protection. OECD Journal on Development [serial online]. 2009; 9(4). ISSN 1816-8124, Available from: www.oecd.org/dac/poverty

11. Malawi Code II of Best Practice for Corporate Governance in Malawi: Sector Guidelines for Listed Companies. Blantyre: Institute of Directors (Malawi); 2010.

12. Mines and Minerals (MM) Act (Cap. 61:01) of 1981, Malawi Government (MG) [statute on the Internet]. Available from: www.parliament.gov.mw/ Malawi Parliament Publisher.

13. Environmental Management (EM) Act of 1996, Malawi Government (MG) [statute on the Internet]. Available from: www.parliament.gov.mw/ Malawi Parliament Publisher.

14. Labour Relations Act (LRA) No. 16 of 1996, Malawi Government (MG) [statute on the Internet]. Available from: www.parliament.gov.mw/ Malawi Parliament Publisher.

15. Occupation Safety, Health and Welfare Act (OSHWA) No. 21 of 1997, Malawi Government (MG) [statute on the Internet]. Available from: www.parliament.gov.mw/ Malawi Parliament Publisher.

16. Employment Act (Cap. 55:01) of 2000, Malawi Government (MG) [statute on the Internet]. Available from: www.parliament.gov.mw/ Malawi Parliament Publisher.

17. Workers Compensation Act (WCA) No. 7 of 2000, Malawi Government (MG) [statute on the Internet]. Available from: www.parliament.gov.mw/ Malawi Parliament Publisher.

18. Pension Act (PA) No. 11 of 2011, Malawi Government (MG) [statute on the Internet]. Available from: www.parliament.gov.mw/ Malawi Parliament Publisher.

19. Kevin C. Bureau of Mines / Minerals Year Book. International Reports, Vol. 3, p. 994. Mining Statistics Bureau; 1986.

20. Maneya GJ. An Integrated Study of Coal Geology and Potential Environmental Impact Assessment at Mchenga Coal Mine in Livingstonia Coalfield in Malawi [unpublished Master of Science thesis on the Internet]. Pretoria: University of Fort Hare; 2012.

21. Samuelson PA, Nordhaus WD. Economics. 15th edition. New York: McGraw- Hill; 1995.

22. Malawi Government-Ministry of Labour Rumphi District Labour Office: Annual Reports of Activities, 2005-2013. Lilongwe: Ministry Headquarters; 2013.

23. Malema KM. Social Protection: The State Regulation of the Employment Relationships in Malawi - Achievements and Challenges. Paper presented at: Chancellor College 2014. During 
proceedings of the University of Malawi Social Science Conference; 2014 June 25 - 27; Zomba, Malawi.

24. Kambilinya IEG. Assessment of Performance of Trade Unions in Malawi [unpublished Masters degree (HRM) thesis on the Internet]. Zomba: University of Malawi; 2008.

25. The Second National Communication of the Republic of Malawi to the Conference of the Parties (COP) of the United Nations Framework Convention on Climate Change (UNFCCC). Lilongwe: Malawi Government-Ministry of Natural Resources, Energy and Environment; 2010.

26. Malema KM. The Role of Labour Inspection in Labour Disputes Settlement Framework in Malawi [unpublished Masters Degree (MBA) thesis]. Blantyre: University of Malawi; 2013.

27. Sustainable Development and Corporate Social Responsibility: Tools, Codes and Standards for the Mineral Exploration Industry. Canada: Government of Canada-Prospectors and Developers Association of Canada (PDAC); 2007.

\section{Appendix}

S1 Appendix: Box 1. Fatal / Accident Report involving the Underground Mine Worker

\section{CPL- MCHENGA COAL MINES LTD - ACCIDENT REPORT - BASE 7, DECEMBER 2011}

On $10^{\text {th }}$ December, 2011 at about 9:00 AM, Alex Songa, aged 38 was involved in a fatal accident at base 7 section of Mchenga coal mine. The accident occurred when the deceased sneaked from fellow workers and went past the barricades into a prohibited mined out area. No one knew he had gone there and his motive for going there remains unclear. All other employees and supervisors were at current working areas. One employee heard a scream and alerted the supervisors who started to search in the direction of the scream. They discovered that Alex Songa had been hit by a rock-fall about $45 \mathrm{~m}$ inside the barricaded area. By that time, he already was hardly breathing. Shift bosses, Brian Mkandawire, Frackson Kanyimbo, Patrick Msowoya and others immediately evacuated him to the surface.

The Mine Manager, Mine Engineer, Senior Mine Overseer and Safety \& Health Environmental officer were alerted and a vehicle was immediately dispatched to transport the injured person to Rumphi district hospital. Alex Songa was pronounced dead on arrival at the hospital. The deceased had been working for Mchenga coal mine as a Trammer for two years, under section of the mine Base 7 as a permanent employee with mine No. 1739 .

The company team investigators found out that Alex Songa disobeyed the standing safety regulations by going into a prohibited and barricaded area. The shift bosses and other employees were busy at the current working areas and no-one knew what the deceased intended to do in that area where he met his fate. Safety talks every time before starting work are conducted where all employees are reminded not to enter into old working areas.

The company in order to reduce or prevent further occurrence of such nature, planned through Mine Overseers, Senior Mine Overseers and Mine Engineers, to always maintain barricades around prohibited areas; to continue safety 
meetings by Safety Supervisors and to be taking disciplinary actions against those workers who do unsafe acts while underground the mines, or elsewhere. The company, however, regretted to have lost Mr Songa, through such unsafe act and felt that the accident could probably have been avoided if the deceased had followed standing safety regulations put in place at the mine.

S2 Appendix: Box 2. Various quotes and report extracts demonstrating positive impact of workers' organizations and their activities at a mining workplace.

We complain of having no freedom of expression because when we try to complain for something, we are being frightened to be dismissed like what happened on $9^{\text {th }}$ September 1996 when the first miners stopped working and went to ask the mine manager on why he was not taking action to their salary scale which had been prepared by his predecessor in December, 1995. Instead the miners were told that if they did not want to work, then they had better leave their jobs and go.

miners, 11st September, 1996.

Striking

We would mention that the following demands have been effected and accepted by you employees: Mk50 per month underground allowance to bonafide underground employees; casual employees have been offered appointments as temporary employees with their salary revised from Mk450.00 to Mk500.00 per month with effect from September 1996 and that the mine will supply fumigation sheet to all employees' not in the mine houses.

Manager, November, 1996.

JA Norton, Mine

I advise you JCCs that you have a role to play between management and workforce and that in future, I would like to meet the workforce regularly at least once monthly to sort small mistakes which may degenerate into big troubles. $\quad C R$ Gilligan, General Manager, August $199 \%$.

Employees are forced to work excess hours without being paid overtime. The contributing factors to the above problems are as follows: improper planning by management in that employees sometimes are delayed to be given Cap lamps, explosives i.e. no enough coal at the ends, inadequate wheelbarrows, lack of protective clothing; Cap lamps going off while tramming, this also make trammers not meet given targets; and compressor breakdowns while tramming is in progress. All these management problems are blamed on trammers forcing them to work excess hours hence very unfair treatment.

JCCs contributions at a meeting with company

management, August, 2004.

JCC and management have agreed on the amendment of chapter 29 subsection 29:5 of Terms and Condition of Services which reads: "Where the death of permanent employee, his wife, or dependent children occurs, the company shall provide a coffin, and transport to and from the place of burial". Now the 
subsection reads as follows: "Where the death of a permanent employee, his wife, children, father and mother occurs, the company shall provide coffin and transport". This new clause has included father and mother.

JCCs resolution, May, 2006.

Management and

As discussed, we have introduced a 12 hour working arrangement for our security section such that guards work 4 days per week with two resting days (off days). After this, they start another working week period. The arrangement still maintains that a guard works 48 hrs during a week.

PE. Ngwira, HRO

communication, September, $200 \%$.

At Mchenga mining company, there is quick submission of accident report forms for processing of compensation awards; there is disciplinary committee as well as JCCs at the workplace; there is a clinic and a school provided by the company at the workplace; there is a contributory pension scheme at the workplace whereby employer contributes $10 \%$; there is SACCO established at the workplace from where some workers who are members can access loans; underground mine workers receive a monthly underground allowance calculated at $5 \%$ of their monthly basic salaries; and employer gives support to some workers who wish to get loans from banks by providing introductory letters and surety.

$$
\text { Rumphi District labour office extract of quarterly }
$$

report, January, 2008. 